Citation: Blagoeva, D., Jaskot, M. P., \& Sosnowski, W. (2019). A lexicographical approach to the contrastive analysis of Bulgarian and Polish phraseology. Cognitive Studies / Études cognitives, 2019(19). https://doi.org/10.11649/ cs. 1923

\author{
DIANA BLAGOEVA ${ }^{1, A}$, MACIEJ PAWEŁ JASKOT ${ }^{2, B}$, WOJCIECH SOSNOWSKI $^{3, C}$ \\ ${ }^{1}$ Institute for Bulgarian Language, Bulgarian Academy of Sciences, Sofia, Bulgaria \\ ${ }^{2}$ Pedagogical University of Cracow, Cracow, Poland \\ ${ }^{3}$ Institute of Slavic Studies, Polish Academy of Sciences, Warsaw, Poland \\ $A_{\text {d.blagoeva@ibl.bas.bg }}$ \\ https://orcid.org/0000-0002-2616-2652 \\ $B_{\text {maciej.jaskot@up.krakow.pl }}$ \\ https://orcid.org/0000-0001-8509-797X \\ $A_{\text {wojciech.sosnowski@ispan.waw.pl }}$ \\ https://orcid.org/0000-0001-9299-4505
}

\title{
A LEXICOGRAPHICAL APPROACH TO THE CONTRASTIVE ANALYSIS OF BULGARIAN AND POLISH PHRASEOLOGY
}

\begin{abstract}
This article discusses the concept behind The Lexicon of Active Bulgarian and Polish Phraseology [Leksykon aktywnej frazeologii bułgarskiej i polskiej] and provides an overview of the key aspects of the methodology used for selecting and composing the dictionary's entries. The authors outline the theoretical underpinnings of this project, touching on the issue of interlingual equivalence, and explain both the process of selecting and verifying phraseological material and the methodology of presenting lexicographical information in the Lexicon. The article includes various examples of active phraseological units from both languages.
\end{abstract}

Keywords: contrastive analysis; phraseology; phraseography; bilingual dictionary of idioms; interlingual equivalence; Bulgarian language; Polish language

\section{Introduction}

The year 2018 saw the centenary of diplomatic relations between Bulgaria and Poland. It was a year of reflections on a hundred years of cooperation on various levels between the two countries. During the conference ${ }^{1}$ held on the occasion of the anniversary, the participants reiterated the need to create new bilingual dictionaries, both traditional and electronic, for didactic and translation

\footnotetext{
${ }^{1} 100$ lat relacji dyplomatycznych między Polska a Butgaria, 6-7.12.2018; Uniwersytet Warszawski (http://slawistyka.uw.edu.pl/pl/2018/11/16/100-lat-relacji-dyplomatycznych-miedzy-polska-a-bulga ria-6-7-12-2018/).
} 
purposes - tools that would enhance the development of cultural, scientific, political and economic relations between Poland and Bulgaria.

The latest lexicographical project of the Bulgarian-Polish scientific team, comprising Diana Blagoeva and Svetla Koeva (from BAN, the Institute for Bulgarian Language), and Maciej Jaskot (from the Pedagogical University of Cracow) and Wojciech Sosnowski (from the Institute of Slavic Studies of the Polish Academy of Sciences), caters to the needs of a wide circle of contemporary users from both countries. The project, work on which began in 2018, aims to create the Leksykon aktywnej frazeologii bułgarskiej i polskiej ${ }^{2}$ (Lexicon of active Bulgarian and Polish phraseology) - the first work of this kind in Slavic lexicography, contrasting the phraseology of Bulgarian and Polish and presenting the current state of the phraseological resources of both languages.

The aim of this article is to outline the basic methodological assumptions adopted during the creation of the Lexicon. The focus will mainly be on issues related to the theoretical basis of the research, the problem of interlingual equivalence, the principles of selection and verification of the presented phraseological material, and the methodology of presenting lexicographical information in the Lexicon.

\section{Status of research}

Despite numerous theoretical and lexicographical studies on Slavic languages, the comparative aspect of Bulgarian and Polish phraseology has yet to be sufficiently investigated. Phraseological information has been partially included in a numer of lexicographical studies such as: Współczesny słownik bułgarsko-polski (Satoła-Staśkowiak \& Koseska-Toszewa, 2014), Bułgarsko-polski słownik leksyki potocznej (Sotirov, Mostowska, \& Mokrzycka, 2011-2013), Leksykon odpowiedniości semantycznych $w$ języku polskim, bułgarskim i rosyjskim (Sosnowski, Koseska-Toszewa, \& Kisiel, 2016), and in three twentieth-century bilingual works: Podręczny słownik bułgarsko-polski z suplementem (Sławski, 1987), Podręczny słownik polsko-bułgarski z suplementem (Radewa, 1988) and Polskie i bułgarskie związki frazeologiczne (Maldžieva \& Wójtowicz, 1994).

Some aspects of the linguistic confrontation between Bulgarian and Polish phraseology have been discussed in individual publications by Sabina Radeva and Jerzy Majchrowski (Radeva \& Maĭkhrovski, 1979), Anna Dolińska (1988), Katarzyna Popova (1998), Iliana Genew-Puhalewa (Pukhaleva, 2003), Snezhina Karag'ozova (2004), Stanka Bonova (2009), Diliana Dencheva (Denczewa, 2013) Elżbieta Michow (2013, 2014) and Ginoeva Ovcharova (2017). The first attempts to confront the latest phraseological Bulgarian-Polish material were presented in the works of Blagoeva, Sosnowski, and Kolkovska (2018) and Sosnowski, Blagoeva, and Tymoshuk (2018). The systematisation of the current phraseological material in dictionary form can stimulate further, more extensive and more in-depth theoretical research with a view to providing a comparative description of the phraseology of both languages.

\section{Basic assumptions of the concept of the Lexicon of active Bulgarian and Polish phraseology}

\subsection{General characteristics of the work}

The Lexicon of active Bulgarian and Polish phraseology will contain over 1,000 phraseological units used actively in contemporary Polish and Bulgarian. An active phraseological unit is to be defined as one that is often used in contemporary language by native speakers in speech and / or writing and is understood by other native users.

The Bulgarian-Polish research team decided that the most important assumptions made and approved while compiling the Lexicon of active Polish and Ukrainian phraseology (Tymoshuk,

\footnotetext{
${ }^{2}$ The publication of the Lexicon is planned for 2020 .
} 
Sosnowski, Jaskot, \& Ganoshenko, 2018) would become the methodological basis of the lexicographical work (being) developed.

Unlike a classical phraseological dictionary, the Lexicon allows phraseological units to be described in a more open manner and it emphasizes the significance of the practical functioning of a given unit in the language system by citing authentic examples, as well as inauthentic ones (see further).

The key advantage of the Lexicon of active Bulgarian and Polish phraseology is the fact that, in addition to general phraseology, it will also include selected phraseological neologisms and phraseological culturemes ${ }^{3}$ (selected on the basis of their wide dissemination) which are active in contemporary language and which are often not fully equivalent, as they reflect the culture of a given nation and its linguistic worldview. As a result, the Lexicon will become part of a broad spectrum of works covering the linguocultural aspect in contemporary lexicography.

\subsection{The notion of phraseological units}

On the basis of the extensive literature on the subject (Bogusławski, 1989; Chlebda, 2003; Lewicki, 1976; Skorupka, 1985) the term phraseological unit can be understood as a set of multicomponent units (consisting of at least two words) which are characterized by semantic anastomosis and reproducibility. Our research, therefore, adopted as a starting point the notion of the phraseological unit as a semantically indivisible and relatively stable unit, expressing complete, special meanings that are not the sum of the meanings of the components of the expression, and which are reproduced in speech as a set lexical configuration. This represents, therefore, an intermediary link between the narrow and broad meaning of phraseology, which is the most convenient for the construction of a bilingual phraseological dictionary.

From the above definition, it follows that phraseological units can only be compared semantically, as - in both languages - phraseological units develop autonomously. The universal definition models developed for the semantic interpretation of phraseological units in both languages became the starting point for the Lexicon. It is unacceptable to set together units on a form-form basis, as this leads to serious methodological errors.

If it is assumed that a phraseological unit is moving towards the word in terms of content, universal definition models can be used to describe phraseological units when contrasting two or more languages. This form of description was adopted in the aforementioned Lexicon of semantic equivalence in Polish, Bulgarian and Russian (Sosnowski et al., 2016), and allows multilingual material to be contrasted.

A review of numerous works devoted to the phraseology of Bulgarian and Polish ${ }^{4}$ indicates that establishing the boundary between a phraseological unit and a non-phraseological unit is complicated. Frequently, when contrasting languages, it is very difficult to decide whether a given unit should be considered as a phraseological unit, since it is difficult to decide which differentiation criteria to apply, i.e. whether to adhere to the Bulgarian or Polish linguistic tradition, as approaches in national linguistic traditions vary considerably. For example, in the Wielki słownik języka polskiego (n.d.) (Comprehensive dictionary of the Polish language), phrases such as: nóz finski, kombinacja norweska, barszcz ukrainski or chłodnik litewski are considered to be phraseological units. In the Bulgarian linguistic tradition, phrases like фински нож, момина сглза, блла мечка, кислородна вода are treated differently, as nominative (terminological) units. Therefore, in Речник на българския език (Dictionary of the Bulgarian language) (Rechnik na bŭlgarskiia ezik, n.d.) they are described separately from phraseology in the strict sense.

After analyzing the material collected for the Lexicon, it was decided that it will include:

\footnotetext{
${ }^{3}$ By culturemes, we understand "key words important for the self-identification of a community, characterizing both its attitude to tradition and coping with the present, current experiencing the world" (Nagórko, Burkhardt, \& Łaziński, 2004). In our research, the scope of this concept is expanded to also inclued the sphere of phraseological vocabulary, which, as it is generally known, is strongly related to the history and culture of a specific community.

${ }^{4}$ Cf. e.g. bibliography collected in works of Bąba, 1998, 2003; Krumova-Tsvetkova \& Blagoeva, 2011.
} 
(a) fixed word collocations, the meaning of which is not the sum of the meanings of their components, e.g. mieć duszę na ramieniu, kopnać w kalendarz, podłożyć (komuś) świnię, szara myszka, cyrk na kótkach, figa z makiem; мәтл главата (на някого), мерл си думите, мед ми капе на душата, бъркам с пргст в раната, гушвам букета.

(b) idiomatic expressions with a specific figurative meaning, containing a component with a literal sense ${ }^{5}$ such as słomiany zapał, sytuacja podbramkowa, wilczy głód; магарешки инат, мокра поргчка.

(c) fixed similes such as głupi jak but z lewej nogi, lać jak z cebra, jak grzyby po deszczu, jasne jak słońcе; мокгр като кокошка, слаб като клечка, мглча като пгн, изчервявам се като домат.

\subsection{Methods of explicating the semantics of phraseological units in the Lexicon}

In the Lexicon of Active Bulgarian and Polish Phraseology, the method of defining phraseological units based on the so-called universal definition models developed for the needs of the aforementioned Leksykon aktywnej frazeologii polskiej i ukraińskiej (Tymoshuk et al., 2018) was applied. The adoption of such a solution made it possible to develop Bulgarian definitions of phraseological units which are analogous to the definitions in Polish. It was only after the Bulgarian definition was provided that the semantically closest unit in the Bulgarian language was assigned to it. Where this was not possible, a descriptive equivalent was used. As emphasized above, one of the methodological assumptions of the Lexicon is to describe a phraseological unit from content to form, as the application of the reverse order (from form to content) is considered by the authors to be potentially misleading since it may create conditions for false phraseological interlinguistic equivalence and other occurrences associated with the distortion of meaning. The third step in describing a phraseological unit was to provide an example of the use of a given unit, which would be the best illustration of its use, while maintaining the pragmatic and stylistic specificity of the given expression.

The examples presented below illustrate the basic universal definition models used in the Lexicon:

(1) 'wtedy, gdy' / 'тогава, когато':

bać się (kogoś lub czegoś) jak diabeł święconej wody

'wtedy, gdy ktoś się bardzo boi kogoś lub czegoś'

Ilona boi się jak diabet święconej wody jeżdzenia samochodem ze swoim szwagrem.

(2) 'o kimś, kto' / 'за някого, който': biedny jak mysz kościelna 'o kimś, kto jest bardzo biedny' Adam jest biedny jak mysz kościelna, nie stać go nawet na porzadne buty.

\section{боя се (от някого или нещо) като дявол от светена вода / от тамян \\ 'тогава, когато някой много се бои от някого или от нещо' \\ Om учителката по математика аз се боях като дявол от светена вода.}

\section{беден като църковна мишка \\ 'за някого, който е много беден' Старият човек, който живее на края на селото, е беден като изр- ковна мишка.}

\footnotetext{
${ }^{5}$ The meaning of these collocations "is within the semantic range of the semantically dominating word, although the whole collocation is semantically irregular" (Lewicki \& Pajdzińska, 2001, p. 319). The cited authors call this type of collocation a phraseme.
} 
(3) 'o czymś, со' / 'за нещо, което':

grubymi nićmi szyte

'o czymś, co jest nieumiejętnie zamaskowane'

Jego zeznania sa grubymi nićmi szyte. Ciekawe, czy sad się na nie nabierze.

\section{шито с бели конци}

'за нещо, което е прикрито по неумел начин'

Историята, която ни разказа, е шита с бели конии, не вярвам и на дума от нея.

(4) 'o kimś (o czymś), kto (со)' / 'за някого (нещо), който (което):

brzydki jak noc (listopadowa) грозен като смъртта (като ку-

kol.

кумявка, крокодил, бостанско

плашило, чума, баба Яга)

'o kimś, kto jest bardzo brzydki'

'за някого, който е много грозен'

Nowa dziewczyna Stawka jest brzydka

Баща ѝ искаше на всяка чена да jak noc.

я омбжи, но тя беше грозна като смгртта и кандидатите бгрзо изчезваха.

'o takim (...), który' / 'за maкzв (...
czeski błąd
'o takim błędzie, który powstaje po-
przez przestawienie znaków'
W jego nazwisku popetniono czeski
bład i wniosek został odrzucony.

\subsection{The issue of the interlinguistic equivalence of phraseological units}

The concept of equivalence is one of the most important in the contrastive analysis of languages and translation studies. M. Jaskot (2016) notes that:

$[\ldots]$ the concept of equivalence when translating culture (indissociable from the language), i.e. "what differentiates and identifies us" (Durdureanu, 2011), becomes a crucial problem. As we have already mentioned, there are thousands of culture-oriented (culture-anchored) terms, which the translator has to deal with. In any respect, the challenge of the translator is to try to produce a PU [phraseological unit] equivalent to the original in the SL [source language], although the concept of equivalence applied to PUs is a dubious one, as it is often difficult to determine whether a PU used as equivalent (total or partial if we want to adopt a gradation) in the TL [target language], can really be considered equivalent.

Nevertheless, to this day a satisfactory definition of the notion of equivalence has yet to be provided. Przemysław Wiatrowski $(2015$, p. 72,2018$)$ draws our attention to the complex and controversial nature of the phenomenon of equivalence. The author points out that "by identifying formally similar and different phraseological units, we deal with the phenomenon described by cognitive scientists as fuzzy categories. Decisions regarding the delimitation of the two types of units will always be arbitrary" (Wiatrowski, 2018, pp. 216-217).

Wojciech Chlebda (2011, pp. 22, 27), on the basis of the type of exponents of equivalence relation, distinguishes between textual equivalence, between the translation of the utterance and its original, and dictionary equivalence (aka. systemic equivalence), which connects the source language unit and the unit of the target language. A similar concept is presented by Dmitry Dobrovol'ski (Dobrovol'skij, 2011), who makes a distinction between translation equivalence and systemic equivalence. Joanna Szerszunowicz focuses on the notion of parallel equivalence. By phraseological parallelisms she means "phraseological units/idiomatic expressions [which exist in two 
or more languages], in which the logical-semiotic model, as well as the metaphorical form of implementation, coincide" (Szerszunowicz, 2004, p. 207).

Systemic equivalence is crucial for bi- or multilingual lexicography (Szerszunowicz \& Vidović Bolt, 2014, p. 201). Wojciech Chlebda presents his own concept of the division of dictionary (systemic) equivalents. The author writes about four types of equivalents and emphasizes that each type is created in turn by a series of subtypes that spread the more or less pertinent equivalents on their axis; in other words, the groups of equivalents which make up particular subtypes and types merge with each other without clear boundaries between them (Chlebda, 2011, p. 38).

1. For the purposes of this article, the authors have agreed to divide the equivalents into four types. The usefulness of this division for lexicographical description has been confirmed by the Polish and Bulgarian phraseological material gathered during the work on the Lexicon. The following types of inter-language equivalence are reflected in the Lexicon: full (or adequate) equivalents ${ }^{6}$ - a unit of language B is equivalent to a unit of language A mainly in terms of meaning and figurativeness (also in terms of pragmatic, stylistic and often grammatical parameters);

\section{bać się własnego cienia}

'wtedy, gdy ktoś się przesadnie boi, jest bardzo ostrożny i podejrzliwy'

Chcesz wyjechać na miesiac do Ameryki Południowej z Andrzejem? Dziewczyno! Przecież on sie boi własnego cienia.

\section{боя се от собствената си сян- ка}

'тогава, когато някой се бои прекалено и е много внимателен и подозрителен'

Тя не смее вечер да ходи сама по улиците, бои се от собствената си сянка.

2. functional equivalents - a unit of language $B$ is equivalent to a unit of language $A$, above all in terms of meaning and its pragmatic function (there may be differences with regard to the figurativeness of the contrasted units, as well as formal differences);

\author{
jechać / pojechać po bandzie \\ kol. \\ 'wtedy, gdy ktoś bardzo w czymś \\ przesadza' \\ Nazywajac szefa starym dziadem, \\ pojechałeś po bandzie. Lepiej za- \\ cznij szukać nowej pracy.
}

\author{
пресолявам / пресоля супа- \\ та / манджата \\ 'тогава, когато някой прекалява, \\ стига до крайност в нещо' \\ Направо пресолихте супата \\ с тези подигравки ком учител- \\ каma.
}

\footnotetext{
${ }^{6}$ Some researchers point out that it is difficult to talk about the full equivalence of phraseological interlanguage equivalents. Joanna Szerszunowicz emphasizes that the existence of a relation of absolute equivalence "should actually be treated as an ideal balance between two phrasemes, which is virtually impossible to achieve in practice, as it must be assumed that subtle differences will appear in the multi-aspect analysis" (Szerszunowicz, 2009, p. 326). These differences may refer to semantics, connotation, variance, frequency, etc. of the phraseological unit of the source language and its equivalent in the target language. Therefore, the above-mentioned author considers it appropriate to replace the term full (absolute) equivalents with the term quasi-equivalents.
} 
iść / pójść po rozum do głowy

'wtedy, gdy ktoś zaczyna zachowywać się rozsądnie'

Długo myślat, jak spłacić kredyt, az w końcu poszedt po rozum do głowy $i$ postanowit zająć się tłumaczeniami, żeby dorobić do pensji.

\begin{abstract}
идва ми / дойде ми акълът в главата

'тогава, когато някой започва отново да се държи разумно'

Беше се увлякбл по една нова колежка, но най-после му дойде акблбт в главата и се вгрна при cәпругата си.
\end{abstract}

3. displaced equivalents - a unit of language B is only partially equivalent to a unit of language A in terms of semantic structure (which is generally associated with pragmatic differences between the two units);

\author{
widać czyją̧ś rękę (w czymś) \\ 'wtedy, gdy ktoś się zaangażował \\ w zrobienie czegoś' \\ $W$ tym doktoracie widać ręke pro- \\ fesora Nowaka.
}

\author{
имам пръст (в нещц) \\ 'тогава, когато някой е замесен \\ в извършването на нещо, обикн. \\ лошо, престъпно' \\ В ограбването на склада вероят- \\ но имат пргст и вгтрешни ли- \\ u,a.
}

4. zero equivalents - there is no ready way of verbalizing the concept, judgement, intentions, emotions, etc. in language B, to which the unit in the language A refers (Chlebda, 2011, pp. 38-39). In the case of zero equivalents, the authors of the Leksykon aktywnej frazeologii bułgarskiej i polskiej used a descriptive technique, i.e. the phraseological unit in question is described by means of the second language, e.g.

\section{czeski film}

'wtedy, gdy nie wiadomo, o co cho-
dzi'
Wasze opowieści z urlopu to jakiś
czeski film!

\section{объркано положение описа- телен еквивалент}

'тогава, когато не се знае за какво става въпрос'

Zero equivalents, called descriptive equivalents in the Lexicon, constitute an interesting group from a contrastive perspective. Menachem Dagut (1981) draws our attention to the existence of two groups of such units. The first group contains phraseological units/idiomatic expressions, the meaning of which is not expressed by the phraseological unit in the target language but which is known and understood by the users of the language. For example, some Polish idiomatic expressions, such as pozjadać / zjeść wszystkie rozumy 'wtedy, gdy ktoś jest przemądrzały i myśli, że wie wszystko' (when someone is big-headed and thinks they know everything) or sto lat za Murzynami 'wtedy, gdy ktoś (coś) jest zacofany(-e)' (when someone/something is backward), do not have equivalent phraseological units in Bulgarian. The second group of zero equivalents, or phraseological gaps, are units whose idiomatic meaning in the source language does not exist in the conceptual universe of the target language users. These units mainly concern culturally-conditioned phraseological units. Traditionally, such units include phraseological units with lexical components referring to the traditions and history of a given community (gest Kozakiewicza, krakowskim targiem, wyjść jak Zabłocki na mydle; като Марко на Косово поле, на Врббница в сряда, Гюоро Михайлов, като иарче Симеончо преди Девети), containing a lexical component related to a given culinary tradition (narobić bigosu, jak paczek w maśle; на баницата мекото, направям на пестил / пастгрма / пита), or forming an inseparable entity, in which the desemantization of the com- 
ponents have reached the highest degree and have made the unit function as a phraseological cultureme.

The concept of phraseological cultureme requires additional explanation. The key to understanding this concept is precisely the lacunar character of a given unit in the connotative sphere (Szerszunowicz, 2004, p. 211), which becomes visible during contrastive research. A full understanding of the phraseological cultureme is possible only by referring to non-linguistic reality and considering the pragmatics of the given unit, as indicated by Jaskot and Ganoshenko (2015, p. 6):

It is natural that the primary task of the adequate reflection of pragmatics which lexicography faces is an adequate understanding of a linguistic sign, overcoming ethno-linguistic barrier, which is obviously based on the asymmetry of ethno-mental culturemes. This means dealing with two (or more) linguistic pictures of the world and with mastering non-equivalent vocabulary.

During work on the Lexicon, some units which are strongly culturally conditioned were found, such as the following examples:

\section{bułkę przez bibułkę}

'o kimś, kto nadmiernie zważa na normy towarzyskie'

Już więcej nie pójdę z Nowakowskimi na kolację. Zupetnie nie mogę się rozluźnić w ich towarzystwie: sa tacy a e butke przez bibutkę.

\section{kiełbasa wyborcza}

'o takich obietnicach kandydata wyborczego, które on składa swoim wyborcom, ale one nie mają pokrycia'

Okazało sie, $\dot{z} e$ projekt ustawy o zwiazkach partnerskich byt kiełbasa wyborcza.

\section{на куково лято разг.}

'тогава, когато нещо няма да се извърши при никакви обстоятелства' Престани да даваш заеми на този човек, не разбра ли, че ще ти вгрне парите на куково лято.

пращам (някого) за зелен хайвер разг.

'тогава, когато някой успява да заблуди, да излъже някого'

Чакам тук вече два часа, а никой не идва, май ме пратиха за зелен хайвер. прекалено превзет човек оnuсателен еквивалент

'за някого, който се държи прекалено официално и превзето в обществото'

\section{неизпълними предизборни обещания описателен еквива- лент}

'за такива обещания, които участващ в избори кандидат дава на избирателите си, но не изпълнява впоследствие'

\section{za Chiny ludowe kol.}

'wtedy, gdy coś na pewno i w żadnych okolicznościach się nie wydarzy' On za Chiny ludowe nie zda tego egzaminu z języka polskiego.

robić / zrobić kogoś w konia / balona / bambuko / trąbę kol. 'wtedy, gdy ktoś kogoś traktuje niepoważnie i oszukuje'

Znów zrobit mnie w konia: pożyczyteś mu pieniadze na rachunki, a on je wydat na imprezy. 
dictionaries of new words), ${ }^{8}$ and electronic corpora. ${ }^{9}$

The use of the corpus analysis method is a new approach in the contrastive description of phraseology and bilingual phraseography (Dobrovol'skiı̌, 2015, p. 24; Filipenko, 2008; Sosnowski, 2016). Speaking of the compilation of translational phraseological dictionaries, Dobrovol'skij notes that: "The advantages of using corpora are clear not only in the more detailed and deliberate exemplification of the described expressions, but also in the additional possibilities that the corpus material provides when compiling the list of entries and the construction of dictionary entries." (Dobrovol'skiǐ, 2015, p. 24).

In particular, based on linguistic data obtained from monolingual corpora one can:

- confirm the fixedness of the examined expression by means of corpus tools for statistical analysis (Przepiórkowski, Bańko, Górski, \& Lewandowska-Tomaszczyk, 2012, pp. 269-270; Szudarski, 2018);

- determine the frequency and range of use of the phraseological unit;

- analyze the contexts in which the phraseological unit is used and draw conclusions about its semantics and possible ambiguities;

- examine the variability of the phraseological unit;

- carry out research on types of texts and communicative spheres in which the phraseological unit functions in order to establish its stylistic value;

- find synonyms and antonyms of the phraseological unit (if any);

- choose the most typical examples illustrating the use of the phraseological unit.

For instance, corpus data enable the use of objective criteria (based on the frequency of use) when choosing the basic lexical or grammatical variant of specific phraseological units (Szudarski, 2018). For example, according to information from the National Corpus of Polish in contemporary Polish written texts, the variant of the phraseological unit nie kiwnać palcem (428 examples) occurs over 5 times more often than the variant nie ruszyć palcem (79 examples).

The authors also noticed that in many cases variants of a phraseological unit containing a perfective verb are used more often than those with an imperfective verb. To illustrate this point, in the National Corpus of Polish Language there are 530 occurences of the variant with the perfective verb odejść z kwitkiem (see Figure 1, p. 11) and almost half as many examples (338) of the variant with the imperfective verb odchodzic z kwitkiem. In the Bulgarian National Corpus, there are 36 examples of the variant of a phraseological unit with the perfective verb пропусна покрай ушите си and only 9 occurences of the variant with the imperfective verb пропускам покрай ушите си (see Figure 2, p. 12).

These observations motivated the decision of the authors to select or construct appropriate illustrative examples that contain the most frequently used verb form. Parallel corpora (bilingual and multilingual) can also be used as a source of linguistic information in the interlinguistic contrasting of phraseological units or in phraseographical practice (Dobrovol'skiı̌, 2015; Filipenko, 2008; Sosnowski, 2016). The data obtained from these corpora can serve as the basis for the selection of an appropriate equivalent of the examined phraseological units of the source language

\footnotetext{
${ }^{8}$ Słownik frazeologiczny PWN (Kłosińska, 2005), Фразеологичен речник на българския език (t. 1-2, Nicheva, Spasova-Mikhaŭlova, \& Cholakova, 1975), Нов фразеологичен речник на българския език (Ankova-Nicheva, 1994) and others; Wielki słownik języka polskiego (n.d.; http://www.wsjp.pl/), Речник на българския език (Rесhnik na bŭlgarskiia ezik, n.d.; http://ibl.bas.bg/rbe/); Słowa, słowa... Czy je znasz? (Smółkowa, 2013), Речник на новите думи и значения в българския език (Pernishka, Blagoeva, \& Kolkovska, 2001), Речник на новите думи в българския език (от края на XX и началото на XXI век) (Pernishka, Blagoeva, \& Kolkovska, 2010) and others.

${ }^{9}$ Narodowy Korpus Języka Polskiego (http://nkjp.pl), Български национален корпус (http://search.dcl.b as.bg/), Polish and Bulgarian corpora on the Sketch Engine platform (https://www.sketchengine.eu/).
} 


\section{= NARODOWY KORPUS NKJP JĘZYKA POLSKIEGO}

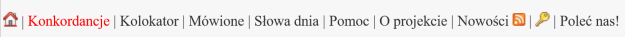

Wyszukiwarka korpusowa PELCRA dla danych $\underline{\text { NKJP }}$ (Cytowanie)

\begin{tabular}{|c|c|c|c|c|}
\hline \multicolumn{5}{|c|}{ odejść z kwitkiem } \\
\hline Maks. odstep: 0 & Zachowaj szyk: $\square$ Wyniki: 200 & $\begin{array}{l}\text { Czas Profil } \\
\end{array}$ & Excel & URL \\
\hline \multirow{2}{*}{ Zaawansowane } & & Podkorpus: [ & & \\
\hline & & & \multicolumn{2}{|c|}{ SZUKAJ } \\
\hline \begin{tabular}{|l|} 
Poprzednie \\
\end{tabular} & & & Naste & ne $\gg$ \\
\hline
\end{tabular}

Przeszukiwany zbiór zawiera 1,524,696,745 stów. Znaleziono 126 akapitów pasujących do zapytania w 0.071s. Bieżąca strona zawiera 126 przykładów z 125 różnych tekstów.

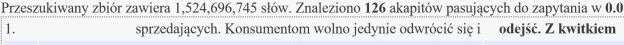
sprzedających. Konsumentom wolno jedynie odwrócić się $\mathrm{i}$ of
A kiedy skończył się czas i musieli 12 funtów zan 12 nawe Wasnego sukcesu. Wielu chętnych musiało odejéć $\mathrm{z}$ kwitkie Hasosci zona odstała w kolejee dwie godziny, aby którzy o nią proszą, są w takiej samej sytuacji maja odejśc z kwitkien Rady Powiatu Zdzisław Sliwwiński z SLD. On również musiał Losów sprzedano łącznie 1200, a wielu chẹtnych musiało odejśc $\mathbf{z}$ kwitkie Ale co miałam zrobić? Wzięlam i tyle. Lepsze to niz̀ odejśc z kwitkiem Osoby, które musiały Chẹtnych było tak duzo, ze wielu rodziców musiało Tłum ludzi czekających na casting musiał salezjańskiej fundaciji, o zwrot pieniędzy bẹdzie musiał aśniak - Mało tego, prawie ją pobito, kiedy nie chciała temu zjawiło się tak dužo chętnych, że większoość musiała otrzymało dwie trzecie wnioskodawców, pozostali muszą było uruchomić kolejną grupę, panie nie mogły przecież tysięcy fanów sportów zimowych i znowu musieli Centrum Krwiodawstwa i Krwiolecznictwa w Słupsku musi

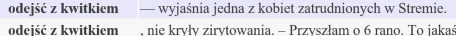

odejsc z kwitkiem

odejś́ $\mathrm{z}$ kwitkiem

odejsć z kwitkiem

odejsć $\mathbf{z}$ kwitkiem
odejś $\mathbf{z}$ kwitkiem

odejsć $\mathrm{z}$ kwitkien

odejsć $\mathrm{z}$ kwitkiem

odejsć z kwitkiem

podszedł do nas ten najwyższy dryblas i powiedzial:

Znajomych mnóstwo. Zwłaszzza ze wsi. W takim tol

sprzed kasy) i $1,2 \mathrm{mln}$ widzów telewwizji Channel 4 ,

ponieważ nieważne, ze figurowala na przydziale. To $j$ ja

To byly zebrania członków, na których omawiano sprawy

PTzyjdą w przyszlą sobotę i beda pracować z

W konstytucji fundacji widnieje bowiem zapis, ze zaden

!

Organizatorzy rozdali 400 numerków, które uprawnialy do

ze wzglẹdu na brak środków.

- Panie z pierwszej grupy ćwiczą z nami jüz ponad trzy

Wprawdzie konkurs się rozpocząl, swoje próby wykonało

odejść $\mathbf{z}$ kwitkiem . Okazuje się, že krwi jest zbyt dužo

\begin{tabular}{|c|c|}
\hline \multicolumn{2}{|l|}{ Jazeta Wroclawska } \\
\hline Weiser Dawidek & \\
\hline Pamiętrnik Pani Hanki... & \\
\hline olityka & \\
\hline olityka & \\
\hline Polityka & \\
\hline Tygodnik Ciechanows... & \\
\hline Nowiny Raciborskie & \\
\hline Tygodnik Tucholski & \\
\hline Zziennik Zachodni & \\
\hline Trybuna Śląska & \\
\hline Trybuna Śląska & \\
\hline Trybuna Śląska & \\
\hline Trybuna Śląska & \\
\hline Trybuna Śląska & \\
\hline Trybuna Śląska & \\
\hline Trybuna Śląska & \\
\hline Trybuna Śląska & \\
\hline Irybuna Śląska & \\
\hline Oziennik Bałtycki & \\
\hline
\end{tabular}

Figure 1: Sample concordance lines for odejść z kwitkiem in the National Corpus of Polish Language

in the target language. However, it should be noted that the material obtained from this type of corpora mainly reflects the translation techniques and strategies used in practice, and therefore the researcher is informed not so much about the system as about the translation equivalence of interlanguage phraseological units.

Among the existing Polish-Bulgarian parallel corpora, Polsko-bułgarski korpus równoległy ${ }^{10}$ (Polish-Bulgarian parallel corpus) is worthy of special mention. This corpus was created by a team of linguists from the Institute of Slavic Studies of the Polish Academy of Sciences and is among the resources of the international CLARIN infrastructure (D. Roszko, R. Roszko, \& Sosnowski, 2018). In the texts contained in the corpus, there are examples illustrating different ways of translating phraseology:

- phraseological unit in language $\mathrm{A} \rightarrow$ phraseological unit of the same meaning and close form in language B (full equivalent)

I jeśli jakaś udręczona, chora samica, z której została tylko skóra i kości przez ten nieustajacy bieg, pozostawała $w$ tyle, była natychmiast okrażona, oblepiona, zaduszona w zwartym brzęczeniu komarów.

И ако някоя нещастна болна самка, само кожа и кости от този непрекбснат бяг, изостанеше, тя биваше мигновено обкрбжена, облепена, задушена в плбтното брбмчене на комарите.

- phraseological unit in language $\mathrm{A} \rightarrow$ phraseological unit of the same meaning and of a different form in language B (functional equivalent) (see Figure 3, p. 13)

- phraseological unit in language $\mathrm{A} \rightarrow$ descriptive construction in language B (zero equivalent)

\footnotetext{
${ }^{10}$ Polish-Bulgarian Parallel Corpus, CLARIN-PL digital repository, https://clarin-pl.eu/dspace/handle /11321/536 (R. Roszko, D. Roszko, Sosnowski, \& Satoła-Staśkowiak, 2018).
} 


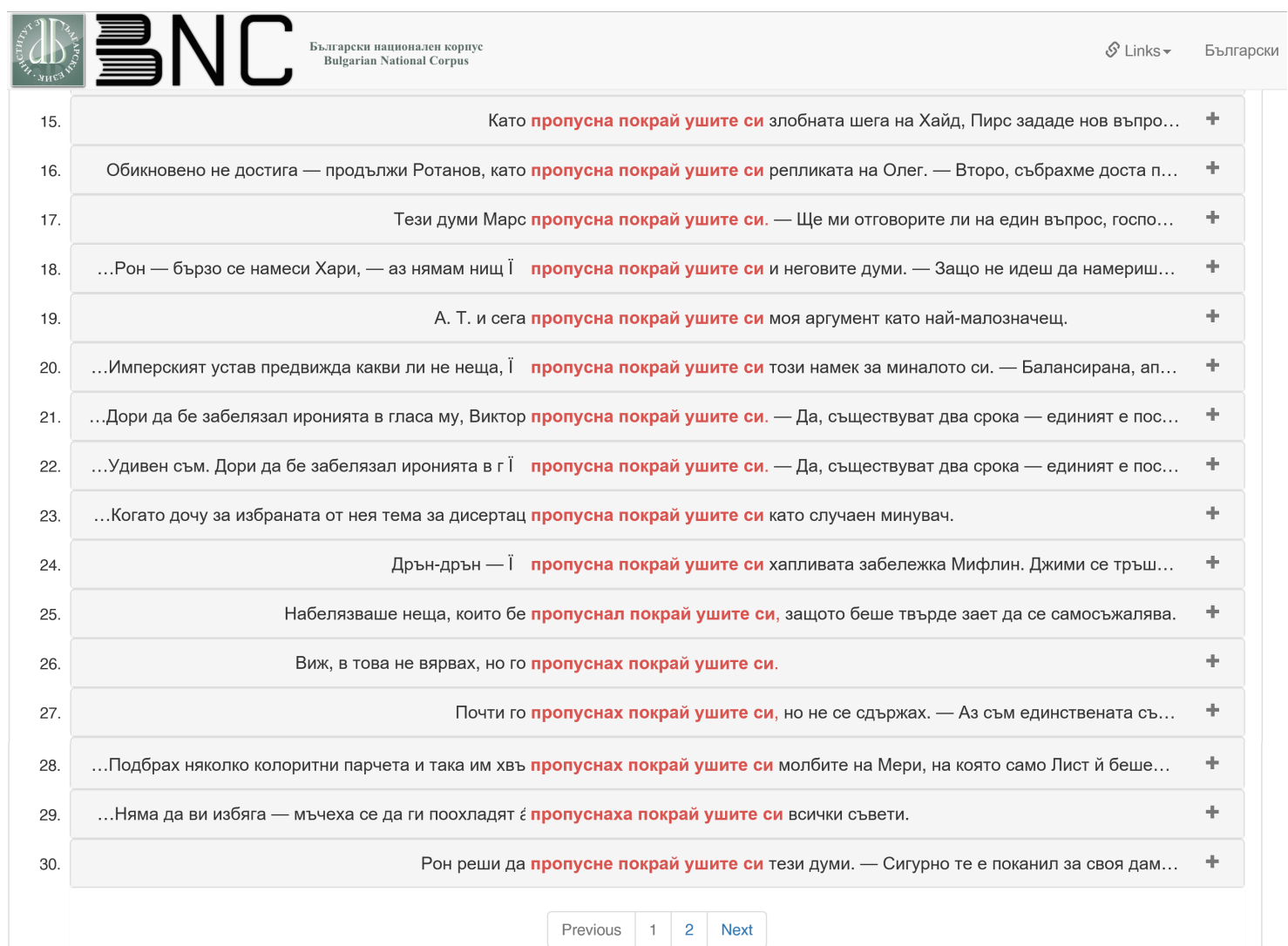

Figure 2: Sample concordance lines for пропускам / пропусна покрай ушите си in the Bulgarian National Corpus

Maria była świadoma swojej urody. Choć zazwyczaj puszczała mimo uszu przestrogi matki, tej jednej nie zlekceważyła: „Córeczko, uroda przemija."

Тя самата впрочем знаеше, че е красива, и вгпреки че често забравяше съветите на майка си, винаги си спомняше за един от тях: „Дбще, красотата е нетрайна."

Naturally, one should be aware that the degree of credibility of the linguistic information obtained from corpora depends largely on the appropriateness of the methods used in the design and creation of the corpus in question. The most important factors in corpus design and creation are the type and scope of the subject, and the scope of the collected materials. Consequently, when researching phraseology, it is worth utilizing corpora with a larger volume and a large variety of texts (Szudarski, 2018, p. 90).

\subsection{General lexigraphical solutions applied in the Lexicon}

The phraseological units in the Lexicon are listed in alphabetical order, according to the Bulgarian alphabet in the Bulgarian-Polish section and according to the Polish alphabet in the PolishBulgarian section. In phraseological units, valent spots are indicated (where necessary), e.g. brak (komuś) piatej klepki, szlag (kogoś) trafit / trafiat / trafia / trafi; слагам / сложа спирачка (на някого, нещо), вдигам / вдигна на балон (някого, нещо), вземам / взема здравето (на някого). The facultative/optional and alternative elements in the entries were separated out based on questionnaires. These elements are presented in two ways: 


\section{kon text}

\section{Query Subcorpora Save Concordance Filter Frequency Collocations View options Help}

\begin{tabular}{|c|c|}
\hline polish_bulgarian_corpus PL & polish_bulgarian_corpus_BG \\
\hline $\begin{array}{l}\text { Nie jesteśmy przeciwko ruchowi Open Source, ale nie } \\
\text { chcemy by nas wrzucano do jednego worka. }\end{array}$ & $\begin{array}{l}\text { doc\#20 Ние не сме против движението за софтуер с отворен код, но не искаме да } \\
\text { ни бъркат с тях и да ни слагат под общ знаменател. }\end{array}$ \\
\hline
\end{tabular}

Figure 3: Sampe concordance lines for the phraseme wrzucić / wrzucać do jednego worka in the Polish-Bulgarian parallel corpus CLARIN

1. Facultative/optional elements are given in brackets: brzydki jak noc (listopadowa); czerpać (реłnymi) garściami (z czegoś); червен като (варен) рак, капят като (гнили) круши.

2. Alternative elements, on the other hand, are shown with a slash: milczeć jak gtaz / skata / grób; jechać na tym samym / jednym wózku; być / poczuć się / czuć się w swoim żywiole; слаб като щека / клечка / вейка, пускам / пусна / пропускам / пропусна покрай ушите си (нещо).

When it is possible to use both the perfective and imperfective forms of verbs in phraseological units, these elements are marked as an alternative: zatykać / zatkać / zapierác / zaprzeć (komuś) dech (w piersiach); dawać / dać (komuś) w kość, dostawać / dostać gęsiej skórki; пускам / пусна кепениите, бргквам / бръкна с пргст в раната.

Occasionally, the entries contain the personal forms of verbs. Personal forms are given in the past / present / future order: włosy (komuś) stanęty / staja / stana dęba.

The meaning of a given phraseological unit is represented by the simplest possible syntax structures. Synonymic definitions are avoided and fragmented definitions are proposed instead.

другата страна на медала
'тогава, когато нещо има и друг ас-
пект (обикновено негативен)'
Другата страна на медала на
спортната слава са различните
травми, от които страдат много
елитни спортисти.

другата страна на медала

'тогава, когато нещо има и друг аспект (обикновено негативен)'

Другата страна на медала на елитни спортисти.

\section{druga strona medalu}

'wtedy, gdy jakaś sprawa ma inny aspekt (zazwyczaj negatywny)'

Ich propozycja jest bardzo atrakcyjna, ale jest też druga strona medalu, czyli koszty.

In the Lexicon, stylistic qualifiers have been used to help the user determine in which situation a given phraseological unit can be used. Units deviating from the general language were marked with three qualifiers: kol. / разг. (colloquial), slang. / жарг. (slang), wulg. / вулг. (vulgar). The first group consists of colloquialisms, i.e. units characterized by a sloppy, free style of expression typical of spoken language, e.g. być na topie, dawać / dać ciała, mieć haka (na kogoś); pumвaм / ритна камбаната, обирам си / обера си крушите. Such phraseological units are on the fringes of the general language and are often considered to be non-normative or less polite. The second group includes phrases used in various social groups, e.g. among young people: bez spiny, jazda bez trzymanki; внимавай в картинката. The third group are vulgarisms, included in the Lexicon due to their frequency of use: burdel na kótkach, gówno prawda, mieć nasrane w głowie / we tbie. 
One of the initial assumptions of the Lexicon was the requirement to illustrate each phraseological unit with an example that would best show its use. Selected examples have been taken from the press, television, and spoken language. Some of the examples have been adapted (i.e. suitably shortened for the needs of the Lexicon). Some of the examples have been specially created. Although some authors refer to specially created examples with skepticism (Bańko, 2001, p. 29), the authors of the Lexicon have noticed their usefulness in the construction of dictionaries of active phraseology. This is due to the fact that the most recent units very often have not yet been recorded in the corpora, and some (especially colloquial units) are still rarely found in the written language.

The purpose of providing phraseological units with examples of their use is also to show the grammatical properties of words (e.g. the verb tense, the inherited prepositional and case requirements of an adjective, or the order of units having specific requirements in this respect). Descriptive equivalents which have been selected for the phraseological units are not illustrated by examples.

\section{Results and final conclusions}

The Lexicon of Active Bulgarian and Polish Phraseology has managed to collect 1,000 active phraseological units in Bulgarian and Polish, some of which are phraseological neologisms. These units largely reflect certain fragments of the linguistic worldview of contemporary Bulgarian and Polish society. One of the advantages of the Lexicon is the proposed method of contrasting phraseological culturemes and other units without equivalents.

The theoretical basis for the work has been developed with a certain degree of compromise, which is necessary due to the significant differences between the Bulgarian and Polish scientific traditions in the field of the theoretical and lexicographical description of phraseological units.

The authors of the Lexicon are of the opinion that, in contrastive research, the approach from content to form is the only acceptable and appropriate way to adequately interpret interlingual similarities and discrepancies. Therefore, universal definition models were applied to semantically describe the phraseological units in the work. In this way, possible methodological errors leading to incorrect interpretations of interlingual equivalence phenomena can be prevented. As a result of the use of universal definitions for phraseological units, any number of other languages (not only Slavic languages) may be added to the Lexicon.

\section{References}

Ankova-Nicheva, K. (1994). Nov frazeologichen rechnik na bŭlgarskiia ezik. Sofiia: UI "Sv. Kliment Okhridski".

Bąba, S. (1998). Materiały do bibliografii frazeologii polskiej: Prace opublikowane w latach 1945-1995. Poznań: "WiS".

Bąba, S. (2003). Materiaty do bibliografii frazeologii polskiej: Prace opublikowane w latach 1996-2000. Poznań: Wydawnictwo "Poznańskie Studia Polonistyczne".

Bańko, M. (2001). Z pogranicza leksykografii i językoznawstwa. Warszawa: Wydział Polonistyki Uniwersytetu Warszawskiego. Retrieved December 27, 2018, from http://www2.polon.uw.edu.pl/banko/plik i/inne/z_pogranicza.tif.pdf

Blagoeva, D., Sosnowski, W., \& Kolkovska, S. (2018). Frazeologichni inovatsii v bŭlgarskiia i polskiia ezik. Balkanistichen forum, 2018(3), 9-20.

Bogusławski, A. (1989). Uwagi o pracy nad frazeologią. In Z. Saloni (Ed.), Studia z polskiej leksykografii współczesnej (Vol. 3, pp. 13-30). Białystok: Zakład Narodowy im. Ossolińskich.

Bonova, S. (2009). Frazeologichni edinitsi, svŭrzani s kristiianstvoto. Bŭlgarsko-polski paraleli. Veliko Türnovo: Ul ,Sv. sv. Kiril i Metodiı“.

Chlebda, W. (2003). Elementy frazematyki: Wprowadzenie do frazeologii nadawcy. Łask: "Leksem". 
Chlebda, W. (2011). Ekwiwalencja i ekwiwalenty: Między słownikiem a tekstami. In W. Chlebda (Ed.), $N a$ tropach translatów: W poszukiwaniu odpowiedników przekładowych (pp. 21-43). Opole: Wydawnictwo Uniwersytetu Opolskiego.

Dagut, M. (1981). Semantic "Voids" as a problem in the translation process. Poetics Today, 2(4), 61-71. https://doi.org/10.2307/1772486

Denczewa, D. (2013). Olej, kapusta, kalosze: Inteligencja i głupota w polskich i bułgarskich związkach frazeologicznych. Postscriptum Polonistyczne, 2(12), 295-301.

Dobrovol'skiǔ, D. O. (2015). Korpusy tekstov i dvuiazychnaia frazeografiia. Vestnik Novosibirskogo gosudarstvennogo pedagogicheskogo universiteta, 5(5), 23-37. https://doi.org/10.15293/2226-3365. 1505.02

Dobrovol'skij, D. (2011). Cross-linguistic equivalence of idioms: Does it really exist? In A. Pamies \& D. Dobrovol'skij (Eds.), Linguo-cultural competence and phraseological motivation (pp. 7-24). Baltmannsweiler: Schneider-Verl. Hohengehren.

Dolińska, A. (1988). Ekwiwalencja somatycznych związków frazeologicznych w języku bułgarskim i polskim. In K. Feleszko (Ed.), Polono-Slavica-Varsoviensia: Vol. 1. Problemy językoznawstwa konfrontatywnego (pp. 189-196). Warszawa: Wydawnictwo Uniwersytetu Warszawskiego.

Durdureanu, I. I. (2011). Translation of cultural terms: possible or impossible? The Journal of Linguistic and Intercultural Education - JoLIE, 4, 51-63.

Filipenko, T. (2008). Korpusnolingvisticheskiı podkhod k analizu semantiki idiom (na materiale nemetskogo i russkogo iazykov). In Izsledvaniia po frazeologiia, leksikologiia i leksikografiia (pp. 59-63). Sofiia: AI "Prof. Marin Drinov".

Gläser, R. (1984). The translation aspect of phraseological units in English and German. Papers and Studies in Contrastive Linguistics, 18, 123-134.

Jaskot, M. (2013). Los asi llamados falsos amigos del traductor entre el español y el esperanto (PhD tesis presented at the University of Warsaw 3.09.2013).

Jaskot, M. (2016). Equivalent culture-anchored units translation? The phraseological units issue. Cognitive Studies / Études cognitives, 2016(16), 57-64. https://doi.org/10.11649/cs.2016.006

Jaskot, M., \& Ganoshenko, J. (2015). Culturemes and non-equivalent lexis in dictionaries. Cognitive Studies / Études cognitives, 2015(15), 115-124. https://doi.org/10.11649/cs.2015.009

Jaskot, M., \& Sosnowski, W. (2017). O fałszywych przyjaciołach tłumacza na przykładzie Leksykonu aktywnej frazeologii polskiej i ukraińskiej. In B. Borkowska-Kępska, G. Gwóźdź, B. Borkowska-Kępska, \& G. Gwóźdź (Eds.), LSP Perspectives 2 Języki specjalistyczne - nowe perspektywy 2 (pp. 55-62). Dąbrowa Górnicza: Wyższa Szkoła Biznesu.

Karag'ozova, S. (2004). Emotsii i mantalitet (Vŭrkhu material ot bŭlgarski i polski frazeologizmi za emotsii). In Ezik i mantalitet (pp. 46-72). Sofiia: Voenno izdatelstvo.

Khutsishvili, S. (2010). Slavianskiie mezh"iazykovye omonimy (Doctoral dissertation). Ivane Javakhishvili Tbilisi State University, Tbilisi. Retrieved December 26, 2018, from http://old.press.tsu.ge/GE0 /internet/disertaciebi/S.Khutsishvili\%20Disertacia.pdf

Kłosińska, A. (Ed.). (2005). Stownik frazeologiczny PWN. Warszawa: PWN.

Krumova-Tsvetkova, L., \& Blagoeva, D. (Eds.). (2011). Bibliografiia po bŭlgarska leksikologiia, frazeologiia i leksikografiia: 1950-2010. Sofiia: AI "Prof. Marin Drinov".

Lewicki, A. M. (1976). Wprowadzenie do frazeologii syntaktycznej: Teoria zwrotu frazeologicznego. Katowice: Uniwersytet Śląski.

Lewicki, A. M., \& Pajdzińska, A. (2001). Frazeologia. In J. Bartmiński (Ed.), Współczesny język polski (pp. 315-333). Lublin: Wydawnictwo Uniwersytetu Marii Curie-Skłodowskiej.

Maldžieva, V., \& Wójtowicz, J. (1994). Polskie i bułgarskie zwiazki frazeologiczne. Warszawa: Wydawnictwa Uniwersytetu Warszawskiego.

Michow, E. (2013). Studia nad frazeologia somatyczna języka polskiego i bułgarskiego. Kielce: GlobalTranslator.

Michow, E. (2014). Semantyka polskich i bułgarskich frazeologizmów somatycznych motywowana funkcjami części ciała człowieka. Kielce: Global Translator.

Nagórko, A., Burkhardt, H., \& Łaziński, M. (2004). Dystynktywny słownik synonimów. Kraków: Towarzystwo Autorów i Wydawców Prac Naukowych "Universitas".

Nicheva, K., Spasova-Mikhaǔlova, S., \& Cholakova, K. (1975). Frazeologichen rechnik na bŭlgarskiia ezik (Vols. 1-2). Sofiia: BAN. 
Ovcharova, G. (2017). Frazeologichni edinitsi s komponent "oko": Bŭlgarsko-polski paraleli. Studia Philologica Universitatis Velikotarnovensis, 36(2), 273-283.

Pernishka, E., Blagoeva, D., \&. Kolkovska, S. (2001). Rechnik na novite dumi i znacheniia v bŭlgarskiia ezik. Sofiia: Nauka i izkustvo.

Pernishka, E., Blagoeva, D., \&. Kolkovska, S. (2010). Rechnik na novite dumi v bŭlgarskiia ezik (ot kraia na XX i nachaloto na XXI vek). Sofiia: Nauka i izkustvo.

Popova, K. (1998). Semantichni aspekti na frazeologizmite s komponent nazvanie na khrana $i$ obleklo (vŭrkhu materiali ot bŭlgarskiia, polskiia i litovskiia ezik) (Dissertation). Sofiia.

Przepiórkowski, A., Bańko, M., Górski, R. L., \& Lewandowska-Tomaszczyk, B. (Eds.). (2012). Narodowy Korpus Języka Polskiego. Warszawa: Wydawnictwo Naukowe PWN.

Pukhaleva, I. (2003). Otsenŭchni frazeologichni edinitsi v bŭlgarski, novogrŭtski i polski ezik (Dissertation). Sofiia.

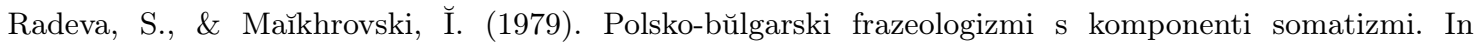
Sŭpostavitelno izuchavane na chastnite leksikalni sistemi na slavianskite ezitsi $v$ sinkhroniia $i$ diakhroniia (pp. 178-183). Sofiia: BAN.

Radewa, S. (1988). Podręczny słownik polsko-bułgarski z suplementem (2nd ed. with suppl., Vols. 1-2). Warszawa: Wiedza Powszechna.

Rechnik na bŭlgarskiia ezik. (n.d.). Retrieved from http://ibl.bas.bg/rbe/

Roszko, D., Roszko, R., \& Sosnowski, W. (2018). Polsko-bułgarskie korpusy IS PAN i CLARIN-PL. Slavica Lodziensia, 2, 59-70. https://doi.org/10.18778/2544-1795.02.05

Roszko, R., Roszko, D., Sosnowski, W., \& Satoła-Staśkowiak, J. (2018). Polish-Bulgarian Parallel Corpus, CLARIN-PL digital repository. Retrieved from https://clarin-pl.eu/dspace/handle/11321/536

Satoła-Staśkowiak, J., \& Koseska-Toszewa, V. (2014). Współczesny słownik bułgarsko-polski (Vol. 1). Warszawa: Instytut Slawistyki PAN.

Skorupka, S. (1985). Stownik frazeologiczny języka polskiego. Warszawa: Wiedza Powszechna.

Sławski, F. (1987). Podręczny słownik bułgarsko-polski z suplementem (2nd ed. with suppl., Vols. 1-2). Warszawa: Wiedza Powszechna.

Smółkowa, T. (Ed.). (2013). Słowa, słowa.. . Czy je znasz? Kraków: Instytut Języka Polskiego PAN.

Sosnowski, W. (2016). Computerised and corpus-based approaches to phraseology: monolingual and multilingual perspectives [Fraseología computacional y basada en corpus: perspectivas monolingües y multilingües (Trabajos completos)] (pp. 339-349). Geneva: Tradulex.

Sosnowski, W. P., Blagoeva, D., \& Tymoshuk, R. (2018). New Bulgarian, Polish, and Ukrainian phraseology and language corpora. Cognitive Studies / Études cognitives, 2018(18). https://doi.org/10. 11649/cs. 1768

Sosnowski, W., Koseska-Toszewa, V., \& Kisiel, A. (2016). Leksykon odpowiedniości semantycznych w języku polskim, bułgarskim i rosyjskim. Warszawa: Instytut Slawistyki PAN.

Sosnowski, W., \& Tymoshuk, R. (2017). Konfrontacja językowa polskich i ukraińskich jednostek frazeologicznych na przykładzie materiału z Leksykonu aktywnej frazeologii polskiej i ukraińskiej. In D. Blagoeva (Ed.), Bŭlgarsko-polski studii. Sofiia: Institut na bŭlgarski ezik "Prof. Liubomir Andreŭchich" - BAN.

Sotirov, P., Mostowska, M., \& Mokrzycka, A. (2011-2013). Bułgarsko-polski słownik leksyki potocznej (Vols. 1-2). Lublin: Wydawnictwo Uniwersytetu Marii Curie-Skłodowskiej.

Szerszunowicz, J. (2004). Paralelizmy frazeologiczne w analizie komparatywnej. Białostockie Archiwum Językowe, 2004 (4), 207-220.

Szerszunowicz, J. (2009). Quasi-ekwiwalenty związków frazeologicznych w teorii, frazeografii i translatoryce. Białostockie Archiwum Językowe, 9, 323-346.

Szerszunowicz, J., \& Vidović Bolt, I. (2014). Kulturowe znaczenie komponentu frazeologizmu a jego międzyjęzykowa ekwiwalencja. Białostockie Archiwum Językowe, 2014(14), 195-216. https://doi.org/ 10.15290/baj.2014.14.12

Szudarski, P. (2018). Corpus linguistics for vocabulary. London: Routledge. https://doi.org/10.4324/ 9781315107769

Tymoshuk, R., Sosnowski, W., Jaskot, M., \& Ganoshenko, Y. (2018). Leksykon aktywnej frazeologii polskiej i ukraińskiej. Warszawa: KJV Digital.

Wandruszka, M. (1978). Die 'falschen Freunde' des Übersetzers. In L. Grahers, G. Karlen, \& B. Malmberg (Eds.), Theory and practice of translation (pp. 213-234). Berlin: Peter Lang. 
Wiatrowski, P. (2015). Międzyjęzykowa ekwiwalencja związków frazeologicznych z apelatywnym komponentem relewantnym kulturowo: Na przykładzie indonezyjskich połączeń wyrazowych i ich polskich odpowiedników. Kwartalnik Językoznawczy, 2015(1-2), 62-175.

Wiatrowski, P. (2018). Związki frazeologiczne identyczne oraz podobne formalnie w językach indonezyjskim i polskim. Poznańskie Studia Polonistyczne: Seria Językoznawcza, 25(1), 199-223. https://doi.org/ 10.14746/psps j.2018.25.1.12

Wielki słownik języka polskiego. (n.d.). Retrieved from http://wsjp.pl/index.php?pwh=0

This work was financed by the Polish Ministry of Science and Higher Education.

The authors declare that they have no competing interests. Maciej Paweł Jaskot is also the reviewer of this issue. All the authors participated equally in preparing conception and academic editing of this issue.

This is an Open Access article distributed under the terms of the Creative Commons Attribution 3.0 PL License (http://creativecommons.org/licenses/by/3.0/pl/), which permits redistribution, commercial and non-commercial, provided that the article is properly cited.

(C) The Authors 2019

Publisher: Institute of Slavic Studies, Polish Academy of Sciences 